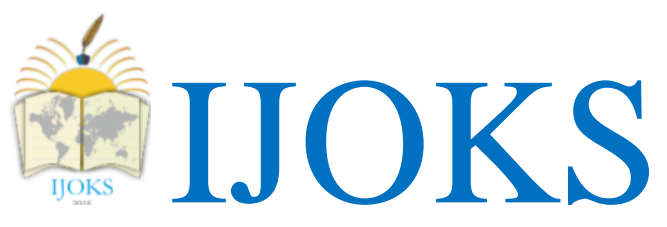

International Journal of Kurdish Studies

(ISSN:2149-2751)

$3(1)$, pp. $1-30$

http://www.ijoks.com

\title{
Son Sınıf Öğrencilerine Göre Beklentileri Karşılama ve Mesleki Hayata Hazırlamada İlahiyat Fakültelerinde Eğitim (Dicle Üniversitesi Örneği)
}

Ali $\ddot{O}_{z e n c ̧}{ }^{1}$

Received: Dec 13, 2016 Reviewed: Dec 31, 2016 Accepted: Jan 08, 2017

\section{$\ddot{O} \mathbf{z}$}

Bu makalede, İlahiyat Fakültelerinin vermiş olduğu eğitimin, öğrencilerin beklentilerini karşılama ve onları hayata hazırlama noktasında hangi düzeyde olduğu Dicle Üniversitesi İlahiyat Fakültesi öğrencileri üzerinden incelenmiştir. Çalışmanın örneklemini adı geçen fakültede 2012-2013 eğitim-öğretim yılında öğrenimlerini sürdürmekte olan son sınıf öğrencileri oluşturmaktadır. Bu araştırmanın amaçlarından ilki, bu öğrencilerin İlahiyat Fakültesinden beklentilerini ve bunların karşılanma durumunu ortaya koyarak, onların mezuniyet sonrasında ne tür duygularla topluma katıldıklarını tespit etmektir. İkincisi, İlahiyat Fakültelerindeki eğitim kalitesinin ve fakülte-öğrenci-hoca üçgenindeki ilişkilerin daha sağlıklı ve verimli olabilmesi adına veriler ve teklifler sunmaktır. Verilerin elde edilmesinde anket, gözlem ve dokümantasyon tekniği kullanılmıştır.

Anahtar Kelimeler: İlahiyat Fakültesi, Dicle Üniversitesi, Beklentileri Karşılama, Mesleki Hayata Hazırlama, Diyarbakır.

\section{Education, from the view of seniors in the faculty of theology in terms of preparing students to career life and meeting students' expectations ( the case of Dicle University)}

\begin{abstract}
This article, the level of the education in theology faculties were studied in terms of meeting students' expectation and preparing them to career life in Faculty of Theology at Dicle University. The sample of the study is based on seniors at the mentioned faculty in 2012-2013 academic year. One of the purposes of this study is to find out students' expectations from the faculty of theology and to see how much these expectations are met and also what their feeling are after the graduation. Another purpose is to provide data and suggestions about the quality of the education, and how to build better relationship within faculty-student-teacher. The data is obtained by survey, observation and documentation tecniques.
\end{abstract}

${ }^{1}$ Dr., E-mail: ozenc43@mynet.com 
Key Words:Theology Faculty, Dicle University, Meeting expectations, Preparing career life, Diyarbakir.

\section{Recommended citation:}

Özenç, A. (2017). Son Sınıf Öğrencilerine Göre Beklentileri Karşılama ve Mesleki Hayata Hazırlamada İlahiyat Fakültelerinde Eğitim (Dicle Üniversitesi Örneği). International Journal of Kurdish Studies 3 (1), 1 - 30 DOI: 10.21600/ijoks.288954

\section{GİRIŞ}

\subsection{Problem, Amaç ve Önem}

İnsan hayatı, anne karnında başlayan ve ölüme kadar devam eden bir eğitim-öğretim sürecinin içinde şekillenmektedir. Bu süreçte insan bazen öğreten olarak özne bazen de öğrenen yani nesne konumunda bulunmaktadır. Eğitim sayesinde birey, öncelikle, yaşadığı toplumun kültürünü öğrenerek toplumsallaşmaktadır. İkinci olarak, globalleşen dünyadaki evrensel değerler ve davranışlar hakkında bilgi sahibi olarak bunlara uyum göstermeye çalışmaktadır (Taştan, Kuşat \& Çelik, 2001: 170).

Birey, eğitim yoluyla sosyalleşmesini sağlayarak yeteneklerini geliştirmekte, eğilimlerini yönlendirmekte ve geçmişten tevarüs eden bilgi birikimlerini içselleştirmektedir (Ayhan, 1999a: 237). Bu birikimlerin elde edilerek tutum ve davranışların şekillendirilmesinde birçok faktör etkili olmaktadır. Kişi üzerinde etkili olan bu etkenlerden birisi de örgün eğitimin son evresini oluşturan üniversitelerdir. Üniversiteler, "geçmişin korunması, bilginin üretilmesi ve yayılması, sosyal ve ahlaki anlamda rehberlik yapma ve toplumsal hayatta gerekli olan nitelikli kadroların yetiştirilmesinde" merkezi kurumlardır (Varış, 1974: 346-347). Söz konusu müesseseler, sahip oldukları imkânlarla o döneme kadar belirli bir kişilik geliştirmiş olan bireylerin hayata atılmadan önce büyük beklentilerle geldikleri yerlerdir. Bünyelerinde barındırdıkları ortamlar ve olanaklarla gençlik üzerinde ciddi bir cazibe meydana getirmektedirler. Öğrenciler buraları, alacak oldukları eğitimden sonra hayata atılıp kendi ayakları üzerinde durmaya başlayacakları, çevre edinecekleri, mesleki yeterliliğe erişme hususunda ve bireysel anlamda kişiliğine olumlu yönde katkıda bulunacak kurumlar olarak görmektedirler.

Yukarıdaki bilgilerden hareketle bu çalışmanın problemi, üniversite bünyelerinde faaliyet gösteren İlahiyat Fakültelerinin, öğrencilerin beklentilerini karşılama, onları mesleki noktada geleceğe hazırlama ve kişiliklerine katkıda bulunma adına ne durumda olduklarının ortaya konulmasidir.

$\mathrm{Bu}$ çalışmanın iki amacı bulunmaktadır: Birincisi, son sınıf öğrencilerinin İlahiyat Fakültesinden beklentilerini ve bunların karşılanma durumunu Dicle Üniversitesi İlahiyat 
Fakültesi örnekleminde inceleyerek, onların mezuniyet sonrasında ne tür duygularla topluma katıldıklarını tespit etmektir. İkincisi, İlahiyat Fakültelerindeki eğitim kalitesinin ve fakülteöğrenci-hoca üçgenindeki ilişkilerin daha sağlıklı ve verimli olabilmesi adına veriler ve teklifler sunmaktır. İlahiyat Fakülteleri sahip oldukları misyon gereği toplumun temel kurumlarından biri olan din eğitimi ile alakalı faaliyetlerin yürütülmesi ve toplumun bu alanda aydınlatılması noktasında gerekli olan din görevlisi, öğretmen ve araştırmacı gibi eleman ihtiyacının karşılandığg kurumlar olarak bilinmektedir (Ayhan, 1999b: 255, 267). Dolayısıyla buradan yetişecek kişilerin mesleki yeterlilik ve kişilik gelişimi açısından sağlıklı bir şekilde hayata katılması büyük önem arz etmektedir. Bu sebeple burada eğitim gören öğrencilerin beklentilerini ve bunların ne ölçüde karşılandığını ortaya koyacak çalışmalara ihtiyaç bulunmaktadır. Bu çalışma, belirtilen konulara çoğunlukla öğrencilerin gözünden yani onların bakış açısıyla bir parça katkı sunmayı amaçlamaktadır.

Ayrıca farklı üniversitelerdeki İlahiyat Fakültelerine dair yapılacak benzer çalışmaların sayısının arttırılması hem bu kurumların eğitim kalitesine hem de buralardan mezun olan öğrencilerin toplum içinde daha faydalı ve donanımlı olmalarına olumlu yönde katkı sağlayacağı düşünülmektedir.

\subsection{Verilerin Toplanması}

$\mathrm{Bu}$ araştırmada verilerin toplanmasında anket, gözlem ve dokümantasyon tekniği kullanılmıştır. Verilerin daha anlaşılır olması için de tablolardan faydalanılmıştır. Tablolarda yüzde ve frekans dağılımı verilmiştir. Anket sorularının hazırlanmasında araştırmacının oluşturmuş olduğu soruların yanı sıra, verileri karşılaştırabilme yapabilme adına Okumuş’un (2007), Kirman ile Apaydın'ın (2006) ve Taştan, Kuşat ve Çelik'in birlikte hazırladıkları (2001) çalışmalardan istifade edilmiştir. Toplam 28 sorunun yer aldığı anket formunda öğrencilerin kişisel bilgileri ve tutumlarıyla ilgili 9, fakülteye yönelik tutumlarına dair 14, beklentilerin karşılanması ve geleceğe dair düşünceleriyle alakalı 5 soru bulunmaktadır. Bu sorular çoktan seçmeli olmakla birlikte bazı sorulara DİĞER seçeneği eklenerek öğrencilerin kendi düşüncelerini ifade etmesi istenmiştir. Öğrencilerin vermiş oldukları cevaplar SPSS'e aktarılarak istatistiki veriler elde edilmiştir. Ortaya çıkan datalar, araştırmacının gözlemleri ve öğrencilerle yaptığı genel görüşmelerle zenginleştirilmiştir. Ayrıca farklı İlahiyat Fakültelerinde yapılan benzer çalışmalarla mukayese yapılmıştır.

$\mathrm{Bu}$ çalışmanın evreni Dicle Üniversitesi İlahiyat Fakültesi bünyesinde yer alan İlahiyat ve İlköğretim Din Kültürü ve Ahlak Bilgisi Öğretmenliği (DKAB) bölümleridir. Örneklemi, bu bölümlerin 2012-2013 eğitim-öğretim yılında okuyan son sınıf öğrencileridir. Son sınıf 
öğrencilerinin seçilmesindeki amaç, ilahiyat eğitiminin sonuna gelmiş olmalarından dolayı, çalışmanın konu ve amacında belirtilen hususların ortaya konulmasında daha sağlıklı bir değerlendirmede bulunacaklarının düşünülmesidir.

Çalışma ile ilgili hipotezler şu şekildedir:

1. Öğrenciler, İlahiyat Fakültesini genellikle dini doğru öğrenmek, öğretmek ve ileride bu alanlarda görev almak istedikleri için seçmişlerdir.

2. Öğrenciler, bazı hocaların ders anlatım yöntemlerinden ve kendilerine karşı olan yaklaşımlarından rahatsızlık duymaktadırlar.

3. Fakültedeki Arapça öğretiminde hocaların formasyon eksikliğinden ve öğrencilerin derse karşı isteksizliğinden kaynaklanan sıkıntılar bulunmaktadır.

4. Öğrencilerin tutum ve davranışlarında eğitime bağlı olarak olumlu ve olumsuz yönde değişimler söz konusudur.

5. Öğrenciler genel itibariyle ilahiyat eğitimi almaktan memnundurlar.

\section{Bulgular}

$\mathrm{Bu}$ çalışmada elde edilen bulgular, kişisel bilgiler ve öğrenci tutumları (2.1), fakülteyle ilgili tutumlar (2.2) ve fakülte sonrası ile ilgili tutumlar (2.3) olmak üzere üç temel başlık altında incelenecektir.

\subsection{Kişisel Bilgiler ve Öğrenci Tutumları}

\subsection{1. Örneklem grubunun cinsiyeti ve bölümü}

Çalışmanın örneklem grubunu 230 öğrenci oluşturmaktadır. Bunların cinsiyet açısından dağılımı incelendiğinde 98'i (\% 42,6) erkek, 132'si (\% 57,4) kadındır. Bölüm açısından incelendiğinde \% 80,4'ü (185 kişi) ilahiyata, \% 19,6'sı (45 kişi) DKAB'a kayıtlıdırlar (Tablo $1)$.

\begin{tabular}{|c|c|c|c|c|c|}
\hline \multicolumn{6}{|c|}{ Tablo 1: Örneklem grubunun cinsiyeti ve bölümü } \\
\hline & & & \multicolumn{2}{|c|}{ Bölüm } & \multirow[b]{2}{*}{ Toplam } \\
\hline & & & İlahiyat & DKAB & \\
\hline \multirow{4}{*}{ Cinsiyet } & \multirow[t]{2}{*}{ Erkek } & Say1 & 77 & 21 & 98 \\
\hline & & Yüzde & $78,6 \%$ & $21,4 \%$ & $42,6 \%$ \\
\hline & \multirow[t]{2}{*}{ Kadın } & Say1 & 108 & 24 & 132 \\
\hline & & Yüzde & $81,8 \%$ & $18,2 \%$ & $57,4 \%$ \\
\hline \multirow{2}{*}{\multicolumn{2}{|c|}{ Toplam }} & Say1 & 185 & 45 & 230 \\
\hline & & Yüzde & $80,4 \%$ & $19,6 \%$ & $100 \%$ \\
\hline
\end{tabular}

Yapılan benzer çalışmalarda (Okumuş, 2007: 64) (Taştan, Kuşat \& Çelik, 2001: 172) (Koç, 2003: 31) da kadınların erkeklere nazaran İlahiyat Fakültesini daha fazla tercih ettikleri 
görülmektedir. Konuyla ilgili olarak yapılan bazı çalışmalarda (Kımter, 2008: 191) (Kurt, 2009: 40-43) (Furseth \& Repstad, 2011: 330) görüldüğü gibi kadınlar, erkeklere nazaran dinî eğitim almaya ve dine ait meseleleri öğrenmeye daha fazla isteklidirler.

\subsubsection{Ailenin ikamet ettiği yer}

Örneklem grubunda yer alan öğrencilerin ailelerinin ikamet ettikleri yerlere göre dağılımı incelendiğinde \% 45,2'si (104 kişi) şehir merkezinde, \% 24,8'i (57 kişi) köyde, \% 24,3'ü (56 kişi) ilçe merkezinde ve \% 5,7'si (13 kişi) kasabada ikamet ettiklerini belirtmişlerdir. Bölümlere göre bakıldığında ise bir değişikliğin olmadığı görülmektedir (Tablo 2).

\begin{tabular}{|l|c|c|}
\hline \multicolumn{3}{|c|}{ Tablo 2: Ailenin ikamet ettiği yer } \\
\hline & Sayı & Yüzde \\
\hline Şehir Merkezi & 104 & 45,2 \\
\hline İlçe Merkezi & 56 & 24,3 \\
\hline Kasaba & 13 & 5,7 \\
\hline Köy & 57 & 24,8 \\
\hline Toplam & 230 & 100 \\
\hline
\end{tabular}

$\mathrm{Bu}$ veriler daha önce yapılan çalışmalarla kıyaslandığında benzerlik göstermektedir. Koç'un yaptığı çalışmada (2003: 33) ailelerin ikamet ettikleri yerler çoktan aza göre il merkezi (\% 46,6), ilçe (\% 27), köy (\% 25,9) ve kasaba (\% 0,5) şeklindedir. Taştan vd.'nin çalışmasında (2001: 173) öğrencilerin \% 94,6’s1 il ve ilçe merkezlerinden gelmişlerdir. Kirman ve Apaydın'ın çalışmasında (2006: 98) öğrencilerin \% 93,4'u büyükşsehir, il ve ilçe merkezlerinde ikamet etmektedir. Bursa'da birinci sınıf İlahiyat Fakültesinde okuyan öğrenciler üzerine yapılan çalışmada (Ay, 2000: 228) \% 77,2’lik bir kesim şehir ve ilçelerde yaşadıklarını belirtmişlerdir. Buna göre İlahiyat Fakültelerinde eğitim almakta olan öğrencilerin büyük bir kısmı şehirde ya da ilçelerde hayat sürmektedirler. Kırsal kesim olarak nitelendirebileceğimiz köylerde yaşayanların çocukları, oran olarak daha azdır.

\subsubsection{Anne-babanın eğitim durumu}

Öğrencilere, anne ve babalarının eğitim durumlarına yönelik bir soru yöneltilmiştir. Bu soruya verilen cevaplar Tablo 3 ve 4'te görülmektedir.

\begin{tabular}{|l|c|c|}
\hline \multicolumn{3}{|c|}{ Tablo 3: Annenin eğitim durumu } \\
\hline & Sayı & Yüzde \\
\hline Okuma-Yazma Bilmiyor & 95 & 41,3 \\
\hline İlköğretim Mezunu & 118 & 51,3 \\
\hline
\end{tabular}




\begin{tabular}{||l|c|c|}
\hline Lise Mezunu & 5 & 2,2 \\
\hline Üniversite Mezunu & 2 & 0,9 \\
\hline Diğer & 10 & 4,3 \\
\hline Toplam & 230 & 100 \\
\hline
\end{tabular}

Öğrencilerin annelerinin \% 41,3’ü (95 kişi) okuma-yazma bilmezken, \% 51,3’ü (118 kişi) ilköğretim, \% 2,2'si (5 kişi) lise, \% 0,9'u (2 kişi) üniversite mezunudur. 10 öğrenci ise (\% 4,3) diğer seçeneğini işaretlemiştir. $\mathrm{Bu}$ kişiler, muhtemelen ilköğretim eğitimini tamamlayamadan okulu terk eden ya da birakmak zorunda kalan ve diploma almaya hak kazanamayanlardır. Buna göre öğrencilerin anneleri çeşitli sebeplerden ya okula hiç gönderilmemiş ya da sadece temel eğitimi almışlardır. Anne konumundaki kadınların arasında okuma-yazma bilmeme oranının bu kadar büyük olması (\% 41,3), ailelerin maddi imkânsızlık içerisinde bulunması, töresel düşüncelerden dolayı kız çocuklarını okutmaya soğuk bakmaları veyahut yaşanılan yerin eğitim olanakları açısından yetersiz olması gibi sebeplere bağlanabilir.

\begin{tabular}{||l|c|c|}
\hline \multicolumn{3}{|c|}{ Tablo 4: Babanın eğitim durumu } \\
\hline & Sayı & Yüzde \\
\hline Okuma-Yazma Bilmiyor & 19 & 8,3 \\
\hline İlköğretim Mezunu & 127 & 55,2 \\
\hline Lise Mezunu & 44 & 19,1 \\
\hline Üniversite Mezunu & 33 & 14,3 \\
\hline Diğer & 7 & 3,1 \\
\hline Toplam & 230 & 100 \\
\hline
\end{tabular}

Tablo 4'teki verilere göre babalarda okuma-yazma bilmeyen kişi sayısı annelere nazaran daha azdır (19 kişi, \% 8,3). Eğitimli babaların çoğu ilköğretim mezunudur (127 kişi, \% 55,2). Lise mezunu 44 (\% 19,1), üniversite mezunu 33 (\% 14,3) baba bulunmaktadır. Diğer seçeneğini işaretleyen 7 kişidir. Taştan vd.'nin yaptı̆ğ çalışmada (2001: 175) annelerin \% 64,2'si, babaların \% 67,1'i ilköğretim mezunudur. Okuma yazma bilmeyen anne (\% 29,6) ve baba (\% 2,1) oranı daha düşüktür. Koç'un araştırmasında (2003: 33) da benzer oranlar görülmektedir. Annelerin \% 61,3'ü, babaların \% 53,9'u ilköğretim mezunudur. Okuma-yazma bilmeyen oranı annelerde $\%$ 20,6, babalarda $\%$ 2,5'tir.

$\mathrm{Bu}$ çalışmalara bakıldığında şunlar söylenebilir: Öncelikle üç çalışmada da okuma-yazma bilmeyen kadın oranı erkeklerden fazladır. Bu durumu, erkeğin ülkemizdeki geleneksel aile anlayışındaki konumuyla açıklamak mümkündür. Erkeğin ayrıcalıklı konumu kendisini eğitim 
alanında da hissettirmiş ve kadınlara göre daha ileri seviyede eğitim almışlardır. İkinci olarak anne ve babaların aldıkları eğitimin büyük oranda ilköğretim ile sınırlandığı görülmektedir. $\mathrm{Bu}$ durumun ortaya çıkmasında eğitim olanaklarının ya da ailelerin maddi imkânlarının yetersizliği veyahut kız ve erkek çocuklarının özellikle kırsal kesimde aile içerisinde üstlenmiş oldukları iş yoğunluğundan dolayı çalışma hayatına erken katıldıklarından, aldıkları eğitimin aileleri tarafından yeterli olduğunun düşünülmesi gelmektedir, denilebilir. Lise ve üniversite mezunu olan anne ve baba oranı düşük seviyelerdedir. Günümüzde ise bu durum tersine bir görüntü sergilemektedir. Kendisinin yeterince okuyamadığını düşünen anne ve babalar, kız erkek ayrımı gözetmeksizin çocuklarının en ileri seviyede eğitim almaları noktasında onları teşvik ettikleri, maddi ve manevi anlamda destekledikleri söylenebilir.

\subsubsection{Anne-babanın meslek durumu}

Tablo 5 ve 6'da anne ve babaların meslek durumlarıyla ilgili veriler yer almaktadır.

\begin{tabular}{|l|c|c|}
\hline \multicolumn{3}{|c|}{ Tablo 5: Annenin meslek durumu } \\
\hline & Sayı & Yüzde \\
\hline Ev Hanımı & 218 & 94,9 \\
\hline Çalışmıyor & 4 & 1,7 \\
\hline Serbest Meslek & 2 & 0,9 \\
\hline Çiftçi & 1 & 0,4 \\
\hline Öğretmen-K.Kursu Hocası & 1 & 0,4 \\
\hline Diğer & 4 & 1,7 \\
\hline Toplam & 230 & 100 \\
\hline
\end{tabular}

Annelerin meslek durumları, okuma-yazma durumlarıyla paralellik göstermektedir. Buna göre okuma ve iş hayatına atılma noktasında yeterince ortam ya da destek bulamayan kadınlar, belli bir vakte gelince evlenmişler ve başka bir işte çalışmayıp evinin hanımı olmuşlardır. Çalışmıyor seçeneğini işaretleyen 4 kişi de dâhil edilirse annelerin \% 96,6'sı (222 kişi) ev hanımıdır. Serbest meslekte çalışan 2, çiftçi 1, öğretmen ya da Kur'an Kursu Hocası 1 anne bulunmaktadır. Diğer seçeneğini işaretleyen 4 öğrenci ise annelerinin mesleki durumunu belirtmemişlerdir. Görüldüğü gibi örneklem grubumuzda yer alan son sınıf öğrencilerinin anneleri mesleki anlamda iş hayatından uzaktırlar.

\begin{tabular}{|l|c|c|}
\hline \multicolumn{3}{|c|}{ Tablo 6: Babanın meslek durumu } \\
\hline & Sayı & Yüzde \\
\hline Çalışmıyor & 14 & 6,1 \\
\hline
\end{tabular}




\begin{tabular}{|l|c|c|}
\hline Serbest Meslek & 31 & 13,5 \\
\hline Çiftçi & 47 & 20,4 \\
\hline Esnaf & 25 & 10,9 \\
\hline İmam-Hatip & 22 & 9,6 \\
\hline Öğretmen-K.Kursu Hocas1 & 5 & 2,2 \\
\hline Diğer & 86 & 37,3 \\
\hline Total & 230 & 100 \\
\hline
\end{tabular}

Öğrencilerin babalarının mesleki durumlarına bakıldığında diğer seçeneğini işaretleyenlerin çoğunlukta olduğu görülmektedir. Bunu işaretleyenlerin sayısı 86, oranı \% 37,3’tür. Bu seçeneği belirten öğrencilerin, babalarının mesleklerine emekli, özel sektör ve devlet memuru yazdıkları görülmektedir. Çiftçi seçeneğini işaretleyenlerin sayısı 47 ( \% 20,4), serbest meslek sahibi 31 (\% 13,5), esnaf 25 (\% 10,9), imam-hatip 22 (\% 9,6), çalışmayanlar $14(\%$ 6,1) ve öğretmen ya da Kur'an Kursu eğiticisi 5 (\% 2,2) kişidir. Görüldüğü gibi serbest meslek sahibi olanların sayısı önemli orandadır. Araştırmacının gözlemlerine ve mülakatlarına göre serbest meslek sahibi olarak ifade edilen kişiler, durumu belirtilen kişiler dişında genellikle düzenli bir işi olmayanlardır. Bu da öğrencilerin babalarının işsizlik ya da düzenli bir işte çalışamama sorunuyla karşı karşıya olduklarını göstermektedir.

\subsubsection{Kendi kişiliğini değerlendirme}

Örneklem grubundaki öğrencilere, kendi kişiliklerini nasıl değerlendirdikleri sorulmuştur. Öğrencilerin \% 31,3’ü (72 kişi) kendisini dini konularda bilgisi yetersiz, \% 13,5’i (31 kişi) kendine aşırı güvenen, \% 10,9'u (25 kişi) kendine güveni olmayan, \% 7,4’ü (17 kişi) sorumluluk almaktan kaçınan, \% 6,1'i (14 kişi) sosyal ilişkilerde zayıf, \% 4,8'i (11 kişi) peşin yargıları olan birisi olarak görmektedir. \% 3,5'i ise (8 kişi) belirtilen seçeneklerin hepsine katıldığını belirtirken, \% 22,5'i (52 kişi) diğer seçeneğini işaretlemiştir (Tablo 7).

\begin{tabular}{|l|c|c|}
\hline \multicolumn{3}{|c|}{ Tablo 7: Kendi kişiliğini değerlendirme } \\
\hline Kendine güvensiz & Sayı & Yüzde \\
\hline Sosyal ilişkilerde zayıf & 25 & 10,9 \\
\hline $\begin{array}{l}\text { Dini konularda bilgisi } \\
\text { yetersiz }\end{array}$ & 72 & 6,1 \\
\hline $\begin{array}{l}\text { Sorumluluk almaktan } \\
\text { kaçınma }\end{array}$ & 17 & 7,4 \\
\hline Kendine aşırı güven & 31 & 13,5 \\
\hline Peşin yargılı & 11 & 4,8 \\
\hline
\end{tabular}




\begin{tabular}{|l|c|c|}
\hline Hepsi & 8 & 3,5 \\
\hline Diğer. Belirtiniz & 52 & 22,5 \\
\hline Toplam & 230 & 100 \\
\hline
\end{tabular}

Buna göre öğrencilerin önemli bir kısmı fakülteyi tercih sebebiyle doğru orantılı olarak kendilerini dini bilgilerde yetersiz görmektedirler. Diğer seçeneklerle birlikte düşündüğümüzde İlahiyat Fakültesinde eğitim alan öğrenciler, kişilikleri noktasında kendilerinde bulunduğunu söyledikleri negatif özelliklerini alacakları ilahiyat eğitimiyle aşacaklarını düşündükleri için bu fakülteyi tercih etmiş olabilirler. Ancak bu öğrenciler belirtmiş oldukları zayıf yönlerini düzeltemeden mezun olmuşlardır. Yani İlahiyat Fakültesi söz konusu eksikliklerin düzeltilmesi hususunda öğrencilere yardımcı olamamıştır, denilebilir. Diğer seçeneğini işaretleyen ve kişilikleri hakkında yorumda bulunanların belirttikleri özellikler ise öz güven sahibi, sabırsız, aşırı duygusal, gelecekten kaygılı, sosyal ilişkileri iyi, kararlı, gayretli, inançlı, dindar, çalışkan, sorumluluk sahibi, kararsız, eleştirici, ahlaklı, dürüst, dinini anlatmaktan zevk alan, anlayışlı, hoşgörülü, empati kurabilen, dini, kaynaklarından öğrenmeye çalışan şeklindedir.

Okumuş'un (2007: 85) çalışmasında öğrencilerin \% 56,6's1, Taştan vd.'nin araştırmasında (2001: 186) \% 48,8'i kişiliğiyle ilgili olarak kendine güvensizlik, çekingenlik, sorumluluk yüklenmekten kaçınma gibi olumsuz ifadeleri belirtmişlerdir. Fakat başka bir çalışmada (Cengil, 2009: 99) ilahiyat öğrencilerinin özgüvenlerinin yüksek, kendisiyle barışık ve olumlu kişilik özelliklerine sahip olduğu görülmektedir.

\subsubsection{Sosyal ilişkilerde kendini tanımlama}

“Kendinizi sosyal ilişkilerinizde nasıl görüyorsunuz?” şeklindeki soruya, öğrencilerin \% 29,1'i İlahiyat Fakültesinde eğitim görmeden dolayı elde etmiş olduğu kimliğin ilişkilerine yön verdiğini yani belirleyici olduğunu, \% 27,8'i girişken, \% 17,9'u çekingen ve içine kapanık, \% 13,9'u fakülte arkadaşları arasında aktif, \% 6,1'i karşı cinse karşı çekingen ve içine kapanık olduğunu beyan etmiştir. Diğer seçeneğini işaretleyen \% 4,8 ise fakülte arkadaşlarıyla pek anlaşamadığını, kendi cinsleri arasında aktif olduğunu belirtmiştir (Tablo 8).

\begin{tabular}{||l|c|c|}
\hline \multicolumn{3}{|c|}{ Tablo 8: Kendinizi sosyal ilişkilerinizde nasıl görüyorsunuz? } \\
\hline & Sayı & Yüzde \\
\hline Çekingen ve içine kapanık. & 41 & 17,9 \\
\hline $\begin{array}{l}\text { İlahiyat kimliğim sosyal ilişkilerimde } \\
\text { çok belirleyici oluyor. }\end{array}$ & 67 & 29,1 \\
\hline
\end{tabular}




\begin{tabular}{||l|c|c|}
\hline Girişken. & 64 & 27,8 \\
\hline İlahiyat arkadaşları arasında aktif. & 32 & 13,9 \\
\hline $\begin{array}{l}\text { Karşı cinse karşı çekingen ve içine } \\
\text { kapanı. }\end{array}$ & 14 & 6,1 \\
\hline Diğer Belirtiniz. & 11 & 4,8 \\
\hline Cevapsız & 1 & 0,4 \\
\hline Toplam & 230 & 100 \\
\hline
\end{tabular}

Aynı soruyla ilgili olarak Okumuş'un araştırmasında (2007: 89) öğrencilerin \% 45,9’u çekingen ve içine kapanık, \% 24,9'u ilahiyat kimliğinin sosyal ilişkilerinde belirleyici olduğunu belirtmiştir.

\subsubsection{Lise eğitiminin alındığı okul}

Son sınıf öğrencilerinin mezun oldukları liseye baktığımızda \% 97,4 (224 kişi) imam hatip liselerinden mezun olmuştur. Bunların \% 60,9'u (140 kişi) normal imam hatip liselerini, \% 36,5'i (84 kişi) Anadolu imam hatip liselerini bitirmişlerdir. Bunun dışındaki liselerden İlahiyat Fakültesini kazanan öğrencilerin sayısı çok azdır (Tablo 9). Bunun en önemli sebebi olarak öğrencilerin üniversiteyi kazandığı sene uygulanmakta olan katsayı problemi söylenebilir. Buna göre imam hatip lisesini bitiren öğrenciler ek puan alarak İlahiyat Fakültelerine kolayca yerleșebilirken, diğer liselerden mezun olanların bu fakülteleri kazanması zor olmaktadır.

\begin{tabular}{||l|c|c|}
\hline \multicolumn{3}{|c|}{ Tablo 9: Lise eğitiminin alındığı okul } \\
\hline & Sayı & Yüzde \\
\hline İHL & 140 & 60,9 \\
\hline Anadolu İHL & 84 & 36,5 \\
\hline Düz Lise & 3 & 1,3 \\
\hline Anadolu Lisesi & 2 & 0,9 \\
\hline Diğer & 1 & 0,4 \\
\hline Toplam & 230 & 100 \\
\hline
\end{tabular}

\subsubsection{Okuduğu bölümü tercih sebebi}

Öğrencilerin ilahiyat ya da DKAB bölümlerini tercih etmelerindeki sebepleri incelediğimizde öğrencilerin büyük bir kısmının $(\%$ 69,2) bilinçli bir şekilde buralara geldikleri görülmektedir. Öğrencilerin \% 39,6's1 “dinimi doğru öğrenmek ve öğretmek için”, \% 29,6's1 “öğretmenlik ve 
din hizmetleri alanında görev almak istediği için” okudukları bölümü tercih ettiklerini söylemişlerdir. Sınav sisteminden dolayı gelenler azımsanmayacak orandadır $(\% 23,9)$. Ailesini kırmamak için İlahiyat Fakültesinde okuyanlar \% 4,3, açıkta kalmamak için bu fakülteyi tercih edenler ise \% 2,6'dır (Tablo 10).

\begin{tabular}{|l|c|c|}
\hline \multicolumn{3}{|c|}{ Tablo 10: Okunan bölümü seçme nedeni } \\
\hline \multicolumn{1}{|c|}{$\begin{array}{l}\text { Dinimi doğru öğrenmek ve öğretmek } \\
\text { icin }\end{array}$} & 91 & 39,6 \\
\hline $\begin{array}{l}\text { Ailem istediği için } \\
\text { Öğretmenlik ve Din Hizmetleri } \\
\text { Alanında Görev Almak İstediğim } \\
\text { için }\end{array}$ & 68 & 29,6 \\
\hline Açıkta Kalmamak için & 6 & 2,6 \\
\hline Sinav sisteminden dolayı & 55 & 23,9 \\
\hline Toplam & 230 & 100 \\
\hline
\end{tabular}

Okumuş'un çalışmasında (2007: 72) öğrencilerin \% 52,2'si, Koç'un araştırmasında (2003: 34) \% 40,7'si, Taştan vd.'nin araştırmasında (2001: 186) \% 53,3'ü “dini doğru öğrenmek ve öğretmek için” İlahiyat Fakültesini tercih ettiklerini söylemişlerdir. Korkmaz'ın yaptığı çalışmada (2000: 189) ise öğrencilerin \% 86'sı dinî ilimlerde daha fazla bilgi sahibi olmak için İlahiyat Fakültesine geldiklerini ifade etmişlerdir.

Verilerden anlaşıldığına göre öğrencilerin önemli bir kısmı dinî anlamda kendini yetiştirmek, daha sonraki süreçte bu alanlarda çalışmak için bu bölümleri tercih ettiğini söylerken, geriye kalan öğrencilerin önemli bir kısmı, o zaman uygulanan sınav sisteminden dolayı bu fakülteye geldiğini belirtmişlerdir. Ailesini kırmamak ve açıkta kalmamak için gelen öğrencilerin sayısı ve oranı diğerlerine nazaran daha azdır.

\subsection{Fakülteyle İlgili Tutumlar}

\subsubsection{Genel Tutumlar}

Genel tutumlar başlığı altında İlahiyat Fakültesinde alınan eğitimin yeterliliği, alınan eğitimin öğrencilerin ve toplumun ihtiyaçlarına cevap verebilme durumu, eğitimin karma ya da ayrı verilmesi, üniversite öğrenimi süresince yaşanan zorluklar ile ilgili veriler incelenmiştir.

\subsubsection{1. İlahiyat Fakültesinde alınan eğitimin yeterliliği}

Öğrencilere almış oldukları ilahiyat eğitiminin yeterli olup olmadığı sorulmuştur. Öğrencilerin sadece \% 1,3’ü kesimi (3 kişi) verilen eğitimin tamamen yeterli olduğunu 
belirtmiştir. \% 72,2'si (166 kişi) eğitimin yetersizliğini, \% 26,5'i (61 kişi) verilen eğitimin kısmen yeterli olduğunu dile getirmişlerdir (Tablo 11). Buna göre öğrencilerin çoğunluğu yeterli seviyede ilahiyat eğitimi alamadıklarını ifade etmişlerdir.

\begin{tabular}{|l|c|c|}
\hline \multicolumn{3}{|c|}{ Tablo 11: İlahiyat Fakültesinde alınan eğitimi genel olarak } \\
yeterli görüyor musunuz? \\
\hline & Say1 & Yüzde \\
\hline Evet & 3 & 1,3 \\
\hline Hayır & 166 & 72,2 \\
\hline Kismen & 61 & 26,5 \\
\hline Toplam & 230 & 100 \\
\hline
\end{tabular}

Hayır cevabı verenlere bunun sebebi sorulduğunda alınan cevaplar aşağıdaki tablodaki gibidir (Tablo 12):

\begin{tabular}{|l|c|c|}
\hline \multicolumn{3}{|c|}{ Tablo 12: Cevabınız hayır ise bunun nedeni nedir? } \\
\hline & Sayı & Yüzde \\
\hline Ders hocalarının formasyon eksikliği & 37 & 21,6 \\
\hline Ders Hocalarının alan bilgisi eksiliği & 12 & 7,0 \\
\hline $\begin{array}{l}\text { Beklentilerimi karşılamaması ve hayal } \\
\text { kırıklığı }\end{array}$ & 98 & 56,8 \\
\hline Fakültenin Fiziki Şartları & 3 & 1,8 \\
\hline Diğer. Belirtiniz & 22 & 12,8 \\
\hline Toplam & 172 & 100 \\
\hline
\end{tabular}

Eğitimi yetersiz ya da kısmen yeterli gördügüünü söyleyen ve bunun nedenlerini ifade eden 172 öğrencinin \% 56,8'i (98 kişi) beklentilerini karşılamamasını ve hayal kırıklığını, \% 28,6'sı (49 kişi) ders hocalarının formasyon ve verdikleri dersle ilgili eksikliklerini, \% 1,8'i (3 kişi) fakültenin fiziki şartlarının yeterli olmamasını dile getirmişlerdir. \% 12,8'i ise (22 öğrenci) diğer seçeneğini işaretlemişlerdir. Bu öğrenciler, eğitimi yeterli görmemeleriyle ilgili olarak eğitim sisteminin yanlış olmasından kaynaklanan sorunları öne sürmüşlerdir. Buna göre çok fazla ders görülmekte, teferruata inilmeden yüzeysel olarak ders işlenmekte ve ezbere dayalı bir eğitim uygulanmaktadır. Bundan dolayı çok verimli bir eğitim alınamamaktadır. Eğitim sistemiyle ilgili olarak dile getirilen başka bir konu da felsefe derslerinin fazla olduğudur. Öğrenciler, felsefe derslerinin görülmesini ilahiyat eğitimiyle bağdaştıramamaktadırlar. Bu hususta hocaların öğrencilere bu derslerin gerekliliğine dair bilgilendirme yapma zorunluluğunun olduğu görülmektedir. Dile getirilen başka bir sorun, 
ders hocalarına dairdir. Bazı ders hocalarının bilgi ve anlatımda yetersiz kaldıkları, bazılarının alanına hâkim olmasına rağmen bunu öğrenciye aktaramadıkları ifade edilmiştir. Ayrıca derste ilgisiz konuların işlenmesi ve öğrenciyle gerektiği şekilde ilgilenilmemesi de diğer hususlardır.

\subsubsection{Alınan eğitimin öğrencilerin ve toplumun ihtiyaçlarına cevap verebilme durumu}

Öğrencilere, almış olduğunuz eğitim sizin ve toplumun dinî ihtiyaçlarına cevap verip veremeyeceği sorulmuştur. Öğrencilerin \% 45,7'si (105 kişi) aldıkları eğitimin özellikle eğitim sisteminden ve müfredattan kaynaklandıklarını belirttikleri sıkıntılardan dolayı kendilerinin ve toplumun dinî ihtiyaçlarını karşılamakta yetersiz olduğunu düşünmektedirler. \% 49,5 (114 kişi) aldıkları eğitimin kısmen belirtilen ihtiyaçlara cevap verebileceğini, \% 3,9 (9 öğrenci) cevap verebilmede yeterli olduğunu ifade etmişlerdir. 2 öğrenci ise $(\% 0,9)$ bu soruya cevap vermemiştir (Tablo 13).

\begin{tabular}{|l|c|c|}
\hline \multicolumn{3}{|c|}{$\begin{array}{c}\text { Tablo 13: Illahiyat Fakültesinde aldığınız eğitimin sizin ve } \\
\text { toplumun dinî ihtiyaçlarına cevap vereceğini düşünüyor } \\
\text { musunuz? }\end{array}$} \\
\hline & Sayı & Yüzde \\
\hline Evet & 9 & 3,9 \\
\hline Hayır & 105 & 45,7 \\
\hline Kısmen & 114 & 49,5 \\
\hline Cevapsız & 2 & 0,9 \\
\hline Toplam & 230 & 100 \\
\hline
\end{tabular}

\subsubsection{Eğitimin karma ya da ayrı verilmesi}

Tablo 14'te öğrencilerin eğitimin kız-erkek karma ya da ayrı verilmesine dair görüşleri yer almaktadır.

\begin{tabular}{|l|c|c|}
\hline \multicolumn{3}{|l|}{ Tablo 14: İlahiyat Fakültesinde eğitimin karma verilmesini } \\
(kız-erkek beraber ) nasıl değerlendiriyorsunuz? \\
\hline & Sayı & Yüzde \\
\hline Karma eğitime devam edilmeli. & 62 & 27,0 \\
\hline Kız-Erkek ayrı eğitim verilmeli. & 132 & 57,3 \\
\hline Fikrim Yok. & 36 & 15,7 \\
\hline Toplam & 230 & 100 \\
\hline
\end{tabular}


Bu konuyla ilgili olarak öğrencilerin \% 57,3’ü (132 kişi) eğitimin kız-erkek ayrı verilmesini, \% 27'si (62 kişi) karma eğitime devam edilmesi gerektiğini, \% 15,7 (36 kişi) ise bu konuda bir fikri olmadığını beyan etmiştir. ${ }^{2}$ Bu verilerin cinsiyete göre dağılımına bakıldığında aşağıdaki gibi bir tablo ortaya çıkmaktadır (Tablo 15):

\begin{tabular}{|l|l|c|c|c|c|c|}
\hline \multicolumn{7}{|c|}{ Tablo 15: İlahiyat Fakültesinde Eğitimin Karma verilmesini (Kız-Erkek beraber ) nasıl } \\
değerlendiriyorsunuz? \\
* Cinsiyetiniz \\
\hline \\
\hline Karma eğitime devam edilmeli. & 24 & 24,5 & 38 & 28,8 & 62 & 26,9 \\
\hline Kiz-Erkek ayrı eğitim verilmeli. & 65 & 66,3 & 67 & 50,7 & 132 & 57,4 \\
\hline Fikrim Yok. & 9 & 9,2 & 27 & 20,5 & 36 & 15,7 \\
\hline Toplam & 98 & 100 & 132 & 100 & 230 & 100 \\
\hline
\end{tabular}

Cinsiyete göre eğitimin verilme şekli değerlendirildiğinde, hem kız hem de erkek öğrencilerin çoğunluğu kız-erkek ayrı eğitim verilmesini gerektiğini ifade etmişlerdir. Ancak karma eğitime devam edilmesini söyleyen veya bu konuda fikir beyan etmeyen kız öğrencilerin sayısı erkeklere nazaran daha fazladır. Bölümlere göre bakıldığında ise bir farklılık bulunmamaktadır. İlahiyat ve DKAB bölümlerinde okuyan öğrencilerin çoğunluğu eğitimin ayrı verilmesi gerektiğini belirtmişlerdir (Tablo 16).

\begin{tabular}{|c|c|c|c|c|c|c|}
\hline & İlahiyat & Yüzde & DKAB & Yüzde & Toplam & Yüzde \\
\hline Karma eğitime devam edilmeli. & 49 & 26,5 & 13 & 28,9 & 62 & 26,9 \\
\hline Kız-Erkek ayrı eğitim verilmeli. & 107 & 57,8 & 25 & 55,5 & 132 & 57,4 \\
\hline Fikrim Yok. & 29 & 15,7 & 7 & 15,6 & 36 & 15,7 \\
\hline Toplam & 185 & 100 & 45 & 100 & 230 & 100 \\
\hline
\end{tabular}

\subsubsection{4. Üniversite öğrenimi süresince yaşanan zorluklar}

Üniversite hayatı verimli olduğu kadar meşakkatli bir dönemi de içerisinde barındırmaktadır. Bununla ilgili olarak örneklem grubunda yer alan öğrencilere üniversite yaşamlarında zorlandıkları ya da sıkıntı çektikleri dört konunun neler olduğu soruldu. Buna dair alınan cevapların toplamında ortaya çıkan tablo aşağıdaki gibidir (Tablo 17):

\footnotetext{
2 Dicle Üniversitesi İlahiyat Fakültesinde 2015-2016 Eğitim-Öğretim y1lından itibaren eğitim, kız-erkek ayrı şekilde verilmeye başlanmıştır.
} 


\begin{tabular}{|l|c|c|}
\hline \multicolumn{3}{|c|}{ Tablo 17: Üniversite öğrenimi süresince yaşanan dört önemli zorluk } \\
\hline & Say1 & Yüzde \\
\hline Aileden uzaklık & 101 & 11,7 \\
\hline Maddi Problemler & 108 & 12,5 \\
\hline Sinavlar & 137 & 15,8 \\
\hline İlahiyat Öğrencilerine Formasyon Verilmemesi & 153 & 17,6 \\
\hline $\begin{array}{l}\text { Fakültenin Sosyo-Kültürel Faaliyetlerinin } \\
\text { Yetersizliği }\end{array}$ & 144 & 16,6 \\
\hline Kütüphane Hizmetlerinin Yetersizliği & 85 & 9,8 \\
\hline Fakültenin Fiziki Şartları & 120 & 13,8 \\
\hline Diğer & 19 & 2,2 \\
\hline Toplam & 867 & 100 \\
\hline
\end{tabular}

Tablo 17 incelendiğinde özellikle İlahiyat Fakültesindeki öğrencilerin üniversite eğitimleri boyunca sıkıntı çektikleri en önemli meselenin ilahiyat öğrencilerine formasyon verilmemesi konusu olduğu görülmektedir (\% 17,6). Örneklem grubunda yer alan ilahiyat bölümündeki öğrenci sayısı (185) dikkate alındığında öğrencilerin büyük çoğunluğu bu problemden muzdarip konumdadır. Bunun dışında sırayla fakültedeki sosyo-kültürel faaliyetlerin yetersizliği (\% 16,6), sınavlar (\% 15,8), fakültenin fiziki şartları (\% 13,8), maddi problemler (\% 12,5), aileden uzakl1k (\% 11,7), kütüphane hizmetlerinin yetersizliği $(\% 9,8)$ ve diğer konular (\% 2,2) gelmektedir. ${ }^{3}$ Diğer seçeneğini işaretleyenler, bazı hocaların Türk, Sünni, Hanefi şeklinde ayrımcılık yapmalarını, kantinin yetersizliğini, okula devam zorunluluğunu, ödevlerin fazla olmasını ve YDS, ALES gibi sınavlara hazırlanmak için zaman kalmamasını, ulaşım, yemek, kalacak yer, protesto ve eylemler ile kendi ailevi sorunlarını dile getirmişlerdir.

\subsubsection{Derslerle İlgili Tutumlar}

Bu başlık altında en çok zorlanılan dersler, Arapça dersindeki öğretim metodu, Felsefe ve Din Bilimleri derslerine bakış, geleneksel din anlayışına ters düşen fikirlerin tartışılması konuları incelenmiştir.

\subsubsection{En çok zorlanılan dersler}

Öğrencilerden mezun olana kadar almış oldukları dersler içinde en çok zorlandıkları dersleri belirtmeleri istenmiştir. Alınan cevaplar Tablo 18'deki gibidir.

\footnotetext{
3 Fakültenin ve kütüphanenin fiziki şartlarıyla alakalı olarak, çalışmanın yapıldığı dönemden bugüne önemli ölçüde iyileştirmenin yapıldığı öğrenciler tarafından dile getirilmektedir.
} 


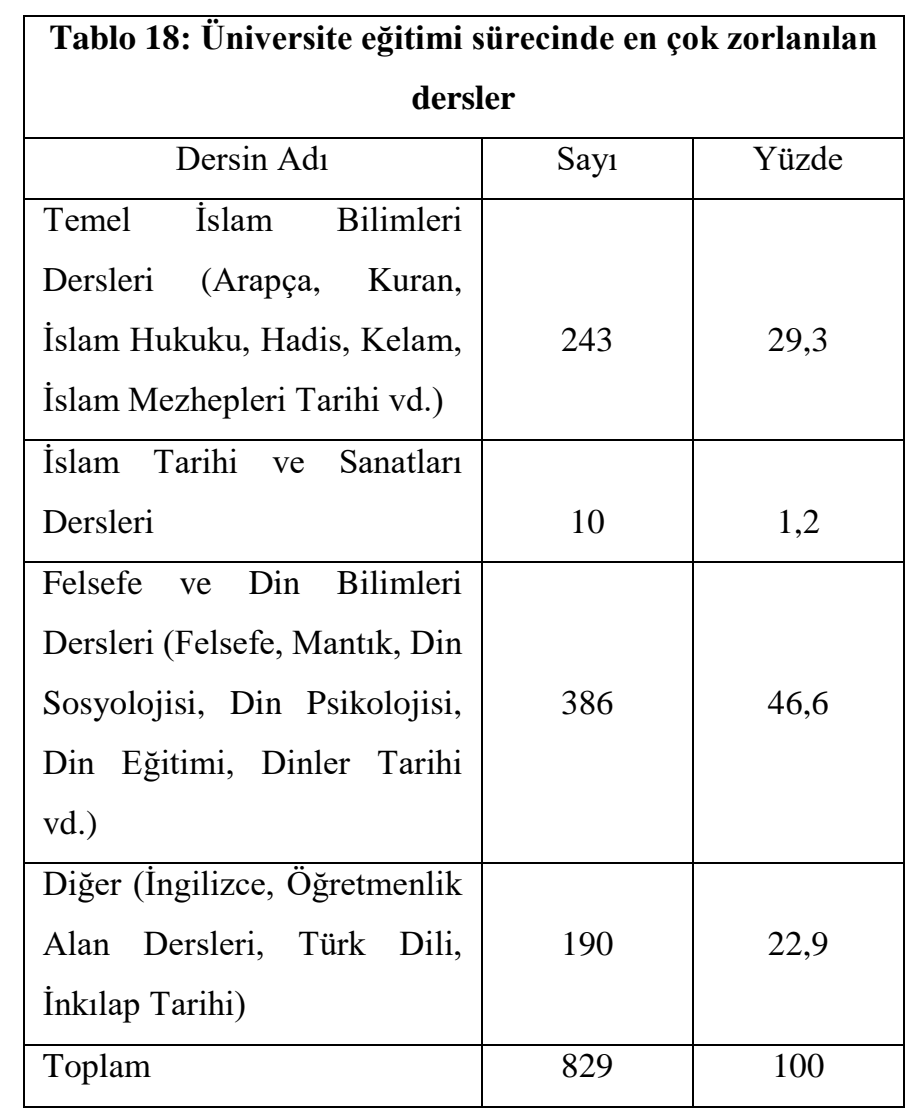

$\mathrm{Bu}$ soruyu cevaplarken öğrencilere 4 derse kadar işaretleme izni verilmiştir. Bunun sonucunda ortaya çıkan tablo incelendiğinde öğrencilerin \% 46,6'sı (386 kişi) Felsefe ve Din Bilimleri dersleri olarak adlandırılan Mantık (121 kişi), Felsefe (110 kişi), Din Sosyolojisi (91 kişi), Din Psikolojisi (34 kişi), Din Eğitimi (17 kişi) ve Dinler Tarihi (13 kişi) derslerinden zorlandıklarını söylemişılerdir. \% 29,3’ü (243 kişi) Temel İslam Bilimleri bölümünde yer alan Arapça (106 kişi), Kelam (64 kişi), Kur'an-1 Kerim (24 kişi), İslam Hukuku ve Hadis (19’ar kişi) ile İslam Mezhepleri Tarihi (14 kişi) derslerini zorlanılan dersler olarak belirtmişlerdir. \% 22,9'u (190 kişi) ise ilahiyat bölümüyle doğrudan bağlantılı olmayan ve daha çok dışarıdan gelen öğretim elemanları tarafindan okutulan İngilizce (86 kişi), İnkılâp Tarihi (68 kişi), Türk Dili (24 kişi) ve öğretmenlik alan derslerini (12 kişi) belirtmişlerdir. Kendilerini İslam Tarihi ve Sanatları Bölümü derslerinin zorladığını söyleyen öğrencilerin oranı ise \% 1,2 (10 kişi)'dir. Bölüm olarak bakıldığında öğrencilerin en fazla Felsefe ve Din Bilimleri Bölümü derslerinden, özelde ise Mantık, Felsefe ve Arapça derslerinden zorlandıkları anlaşılmaktadır. Felsefe ve Mantık derslerinde öğrencilerin sıkıntı yaşaması birkaç sebepten kaynaklanabilir: İlk olarak İslam toplumlarında bu derslere karşı yaygın olan olumsuz yargı (Toktaş \& Acuner, 2004: 173) ikincisi, özellikle Temel İslam Bilimlerindeki ders hocalarının kendi derslerini 
daha fazla ön plana çıkarıp, Felsefe derslerinin gereksizliğini öğrencilere telkin etmesi, üçüncüsü ders hocalarının dersi sevdirememesi, dördüncüsü, bu derslerle ilgili olarak önceden yeterli bir alt yapının olmaması, beşinci ve son olarak da, öğrencilerde bu derslerin ilahiyat müfredatında gereksiz olduğu düşüncesinden meydana gelen bir isteksizliğin bulunması belirtilebilir.

Bu sıkıntının aşılması adına yukarıda ifade edildiği şekliyle dönem başında bu derslerin, bir araştırmada (Taşkıran, 2013: 238) belirtildiği gibi ilahiyat eğitimindeki öneminin ve öğrencilerin "eleştirel, sorgulayıcı, toplumun her kesimini kapsayan hoşgörülü bir bakış açısı ve din anlayışı geliştirmelerinde son derece fonksiyonel olduğunun" anlatılması önemli olacaktır.

Arapça dersinden zorluk yaşanmasının en önemli sebebinin ülkemizdeki dil öğrenme ya da öğretme sıkıntısı ile alakalı olduğu söylenebilir. Çünkü imam-hatip ortaokulundan itibaren alınan Arapça eğitimi, üniversiteden mezun olurken bile bir sıkıntı olarak düşünülmekte ve istenen verimin elde edilemediği görülmektedir. İngilizce'nin de en çok zorlanılan dersler arasında yer alması aynı sıkıntı ile alakalı olabilir. Dil öğrenmeye yönelik derslerde ezberin yanında uygulamanın olması ve öğrencilerin gündelik hayatta ya da yurt dışına yapılacak gezilerle pratik kazanmalarının sağlanması bu sıkıntıları aşma adına önemli bir adım olabilir.

\subsubsection{Arapça öğretim metodu}

Arapça öğretim metodunun yeterli olup olmadığı örneklem grubunda yer alan öğrencilere sorulmuştur. Öğrencilerin \% 77'si Arapça öğretim metodunun doğru ve yeterli olmadığını, \% 20,8'i kısmen, \% 2,2'si tamamen yeterli olduğunu belirtmişlerdir (Tablo 19).

\begin{tabular}{|l|c|c|}
\hline \multicolumn{3}{|c|}{$\begin{array}{c}\text { Tablo 19: Arapça öğretim metodunun } \\
\text { doğru ve yeterli olduğunu düşünüyor } \\
\text { musunuz? }\end{array}$} \\
\hline & Sayı & Yüzde \\
\hline Evet & 5 & 2,2 \\
\hline Hayır & 177 & 77,0 \\
\hline K1smen & 48 & 20,8 \\
\hline Total & 230 & 100 \\
\hline
\end{tabular}

Okumuş'un çalışmasında (2007: 75) Arapça dersinde izlenen yöntemi beğenenlerin oranı \% 15,1, kısmen diyenler \% 27,3, beğenmeyenler \% 52,7'dir. Görüldüğü üzere Dicle Üniversitesi İlahiyat Fakültesinde o tarihten bu yana Arapça dersinin yöntemini beğenmeyenlerin ve 
yeterli olmadığını düşünenlerin sayısı artmıştır. Bunun sebepleri incelendiğinde öğrenciler aşağıdaki sıkıntıları dile getirmişlerdir (Tablo 20):

\begin{tabular}{|l|c|c|}
\hline \multicolumn{3}{|c|}{ Tablo 20: Cevabınız hayır ise bunun nedeni nedir? } \\
\hline & Sayı & Yüzde \\
\hline $\begin{array}{l}\text { Bilgi yönünden donanım ve } \\
\text { yeterliliklerini öğrencilere } \\
\text { yansıtamıyorlar. }\end{array}$ & 52 & 29,4 \\
\hline $\begin{array}{l}\text { Öğrencilerle sosyal ilişkileri soğuk ve } \\
\text { resmi. }\end{array}$ & 15 & 8,5 \\
\hline Ders anlatım yöntemleri & 90 & 50,8 \\
\hline Diğgr.Belirtiniz & 20 & 11,3 \\
\hline Toplam & 177 & 100 \\
\hline
\end{tabular}

Tablo 20'ye bakıldığında Arapça öğretim metodunun doğru ve yeterli olmadığını belirten öğrencilerin \% 50,8'i sorunun hocaların ders anlatım yönteminden, \% 29,4'ü hocaların bilgi yönünden donanım ve yeterliliklerini öğrencilere yansıtamamalarından, \% 8,5'i öğrencileriyle ilişkilerinin soğuk ve resmi olmasından, \% 11,3'ü başka nedenlerden kaynaklandığını ifade etmişlerdir. Başka nedenlerle ilgili olarak, derslerin ezbere dayalı olup çok fazla pratiğin olmaması, ders sayısının yetersizliği, gramer konularına ağırlık verilmesi, hocaların dersi sevdirmeye çalışmaması, sınıfların öğrencilerin dil seviyesine göre düzenlenmemesi, teknolojik imkânlardan yeterince faydalanılmaması ve konuların anlatımı esnasında aceleci davranılması dile getirilmiştir.

\subsubsection{Felsefe ve Din Bilimleri derslerine bakış}

Yukarıda görüldüğü (Tablo 18) gibi öğrenciler en çok Felsefe alanıyla ilgili derslerden zorlanmaktadırlar. Bununla ilgili olarak öğrencilere Felsefe ve Din Bilimleri derslerinin İlahiyat Fakültelerinde okutulmasının gerekli ve faydalı olduğuna inanıp inanmadıkları sorulmuştur. Buna göre öğrencilerin yarısından fazlası (\% 52,2) Felsefe ve Din Bilimleri derslerinin ilahiyat müfredatında olması gerektiğini, \% 37'si bazı çekinceleri olmasına rağmen gerekli ve yararlı olduğunu ifade etmişlerdir. Bu dersleri gereksiz ve faydasız görenlerin oranı ise \% 10,8'dir (Tablo 21). Buna göre İlahiyat Fakültesinde okuyan öğrenciler zorlanmalarına rağmen bu derslerin gerekli olduğunu beyan etmişlerdir. 


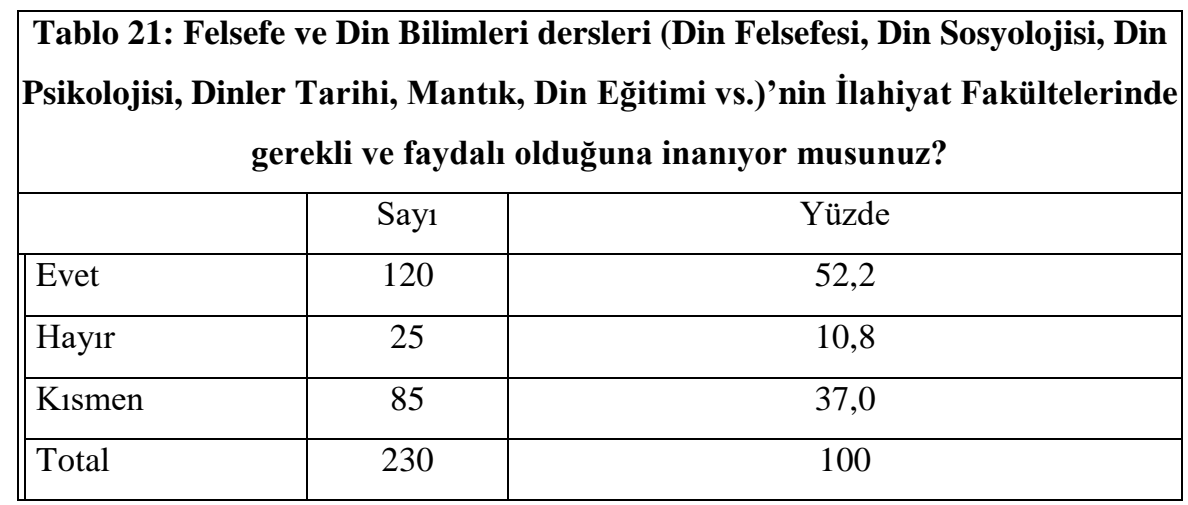

\subsubsection{Geleneksel din anlayışına ters düşen fikirlerin tartışılması}

Çalışmamızdaki bir soruda öğrencilerin, derslerde dile getirilen ve geleneksel din anlayışına ters olarak algılanan konular hakkında ne düşündüklerini ifade etmeleri istenmiştir. Bu soruya öğrencilerin yarısından fazlası (\% 56,1) farklı fikirlerin tartışılmasını gerekli bulduklarını; \% 41,3'ü bu tür konuları tartışmanın yanlış ve gereksiz olduğunu veyahut da dinin temel konuları dururken bu tür konulara girilmesinin rahatsız edici olduğunu; \% 2,6'sı bu konu hakkında bir fikri olmadığını söylemiştir (Tablo 22).

\begin{tabular}{|c|c|c|}
\hline \multicolumn{3}{|c|}{$\begin{array}{l}\text { Tablo 22: Derslerde geleneksel din anlayışına ters düşen fikirlerin } \\
\text { (Peygamber, Sahabe algısı ve Mucizeler vb) tartışılmasını nasıl } \\
\text { değerlendiriyorsunuz? }\end{array}$} \\
\hline & Say1 & Yüzde \\
\hline $\begin{array}{l}\text { Yanlış ve gereksiz olduğunu } \\
\text { düşünüyorum. }\end{array}$ & 51 & 22,2 \\
\hline $\begin{array}{l}\text { Farklı fikirlerin tartışılmasını gerekli } \\
\text { buluyorum. }\end{array}$ & 129 & 56,1 \\
\hline $\begin{array}{l}\text { Dinin temel konuları durur iken bu } \\
\text { tür konulara girilmesini rahatsız } \\
\text { edici buluyorum. }\end{array}$ & 44 & 19,1 \\
\hline Fikrim Yok. & 6 & 2,6 \\
\hline Total & 230 & 100 \\
\hline
\end{tabular}

$\mathrm{Bu}$ veriler bölümler ve cinsiyet açısından incelendiğinde bir farklılaşmanın olmadığı anlaşılmaktadır. Buna göre öğrenciler, üniversite ve fakülte ortamlarını farklı fikirlerin ifade edildiği alanlar olarak düşündüğünden bu konuların tartışılmasını olumlu bulmaktadırlar. Fakat aynı fakültede Okumuş’un yaptığı çalışmada (2007: 67-68) bazı öğrenciler, genel geçer düşünce, yargı ve görüşlere aykırı düşünceleri duyduklarında yıkıldıklarını, diğer bir kısmı ise mevcut dinî yaklaşım ve düşüncelerinin aşağılandığını düşündüğünü ifade etmiştir. Aynı 
fakültede aradan belli bir zaman geçtikten sonra yaşanan bu değişimi modernliğin yaygınlaşmasıyla birlikte insanların geleneksel din anlayışında yer alan ya da buna ters gibi görünen düşünceleri araştırıp, sorgulama ve öğrenme noktasında farklılaşması olarak görebiliriz.

\subsubsection{Ders Hocaları İle İlgili Tutumlar}

$\mathrm{Bu}$ kısımda öğrencilerin fakülte hocalarından beklentileri, memnun olmadıkları hocaların özellikleri, öğrenci işleri ve fakülte idaresiyle ilgili tutumları incelenmiştir.

\subsubsection{Fakülte hocalarından beklentiler}

Öğrencilere "Üniversite hayatınız süresince hocalarınızdan beklentileriniz nelerdi?" şeklindeki soruya öğrencilerin yarıya yakını $(\% 49,6)$ dersini iyi anlatması şeklinde cevap vermiştir. \% 22,2'si öğrenciyle sosyal ilişkilerinin iyi olmasını, \% 20,8'i üniversite sonrası için rehberlik yapmasını yani yol göstermesini beklemişsir. 1 kişinin cevap vermediği soruya diğer seçeneğini işaretleyenlerin (\% 7) beklentileri ise "öğrencileri önemsemeleri, onlara sayg1 göstermeleri, onlarla beraber sosyal aktiviteler gerçekleştirmesi, yaşantılarıyla kendilerine örnek olmalarıdır." Bazı öğrenciler ise şıklarda ifade edilen özelliklerin hepsinin olması gerektiğini söylemişlerdir (Tablo 23).

\begin{tabular}{|l|c|c|}
\hline \multicolumn{3}{|c|}{$\begin{array}{c}\text { Tablo 23: Üniversite hayatınız süresince fakülte } \\
\text { hocalarınızdan beklentileriniz nelerdi? }\end{array}$} \\
\hline \multicolumn{2}{|c|}{ Sayı } & Yüzde \\
\hline $\begin{array}{l}\text { Dersini iyini anlatması. } \\
\text { Öğrenciyle sosyal ilişkilerinin iyi } \\
\text { olması. }\end{array}$ & 114 & 49,6 \\
\hline $\begin{array}{l}\text { Üniversite sonrası için rehberlik } \\
\text { yapması. }\end{array}$ & 48 & 22,2 \\
\hline Diğer. Belirtiniz. & 16 & 7,0 \\
\hline Cevapsı & 1 & 0,4 \\
\hline Toplam & 230 & 100 \\
\hline
\end{tabular}

\subsubsection{Memnun olunmayan hocaların özellikleri}

Eğitim-öğretim faaliyetlerinin hoca ve öğrenci açısından verimliliği, oluşturulacak sağlam bir ilişkiye bağlıdır. Buna rağmen öğrencilerin, bazı hocalarla bunu sağlayamadığı görülmektedir. Bir soruda, öğrencilerden sağlıklı ilişki kuramadıkları yani memnun olmadıkları hocalarının en çok hangi özelliğinin ön planda olduğunu belirtmeleri istenmiştir. Verilen cevapların dağılımı Tablo 24'te gösterildiği gibidir. 


\begin{tabular}{|l|c|c|}
\hline \multicolumn{3}{|c|}{ Tablo 24: Memnun olmadığınız hocaların en çok hangi özelliği } \\
\hline \multicolumn{2}{|c|}{ ön plandadır? } \\
\hline $\begin{array}{l}\text { Bilgi yönünden donanım ve } \\
\text { yeterliliklerini öğrencilere } \\
\text { yansıtamıyorlar. }\end{array}$ & 82 & 35,7 \\
\hline $\begin{array}{l}\text { Öğrencilerle sosyal ilişkileri soğuk ve } \\
\text { resmi. }\end{array}$ & 58 & 25,2 \\
\hline \begin{tabular}{l} 
Örneklik problemi. \\
\hline Ders anlatım yöntemleri.
\end{tabular} & 11 & 4,8 \\
\hline Diğer.Belirtiniz. & 62 & 27,0 \\
\hline Cevapsız & 2 & 6,5 \\
\hline Toplam & 230 & 10,8 \\
\hline
\end{tabular}

Tabloya göre öğrencilerin \% 35,7'si (82 kişi) hocaların sahip oldukları donanım ve yeterliliklerini öğrencilere yansıtamadıklarından şikâyet etmektedirler. \% 27'si (62 kişi) ders anlatım yöntemlerden memnun olmadıklarını dile getirirken, \% 25,2'si (58 kişi) öğrencilerle ilişkilerinde soğuk ve resmi olduklarını, \%4,8'i (11 kişi) kendilerine yeterince iyi örnek olamadıklarını belirtmişlerdir. 2 öğrencinin cevap vermediği soruya, 15 kişi $(\%$ 6,5) ise diğer seçeneğini işaretleyerek farklı fikirler öne sürmüşlerdir. Bu öğrenciler, ders hocalarıyla ilgili olarak "sınavları ve notu kendilerine karşı bir korkutma aracı olarak kullanmalarından, derste ders dışı konu işlemelerinden, kendilerine söz hakkı vermemelerinden, öğrenciler arasında ayrım yapmalarından" kaynaklanan memnuniyetsizliklerini ifade etmişlerdir. Görüldüğü üzere öğrencilerin hocalarından memnuniyetsizliği sadece bir sebebe bağlı olmayıp birkaç faktör bunda etkili olmaktadır. Bu tür sıkıntıların sadece bu fakülte için geçerli olmadığı, benzer problemlerin diğer İlahiyat Fakülteleri için de ifade edildiği görülmektedir (Fırat, 1989: 24).

\subsection{4. Öğrenci işleri}

Öğrencilere fakültenin öğrenci işleri ile ilgili düşünceleri sorulmuştur. Bununla alakalı olarak iki ifade verilmiş ve bunlardan hangisinin kendi görüşüne yakın olduğunu ifade etmesi istenmiştir (Tablo 25, 26).

\begin{tabular}{|l|c|c|}
\hline Tablo 25: Öğrenciye yaklaşımı güler yüzlüdür. \\
\hline & Sayı & Yüzde \\
\hline
\end{tabular}




\begin{tabular}{|l|c|c|}
\hline Katılmıyorum. & 183 & 79,6 \\
\hline Kararsızım. & 30 & 13,0 \\
\hline Katılıyorum. & 17 & 7,4 \\
\hline Total & 230 & 100 \\
\hline
\end{tabular}

Örneklem grubundakilere yöneltilen ilk ifade “Öğrenci işlerinin öğrenciye yaklaşımı güler yüzlüdür” olmuştur. Bu düşünceye katılan öğrencilerin oranı \% 7,4, katılmayanlar \% 79,6, kararsızlar \% 13'tür (Tablo 25). Bu verilerden anlaşıldığına göre öğrenci işlerinin öğrenciye yaklaşımında sıkıntılı bir durum söz konusudur. $\mathrm{Bu}$ konunun üzerinde durulması ve düzeltilmesi gerekmektedir.

Öğrencilere yöneltilen ikinci ifade "Öğrenci işleri taleplerimize yerinde ve zamanında karşıllk verir" şeklindedir. Öğrencilerin bununla ilgili tutumlarına bakıldığında \% 62,6's1 katılmadığını, \% 17,4’ü katıldığını, \% 20’si kararsız olduğunu ifade etmiştir (Tablo 26).

\begin{tabular}{|l|c|c|}
\hline \multicolumn{3}{|c|}{ Tablo 26: Taleplerimize yerinde ve zamanında } \\
karşılık verilir. \\
\hline & Sayı & Yüzde \\
\hline Katılmıyorum. & 144 & 62,6 \\
\hline Kararsızım. & 46 & 20,0 \\
\hline Katılıyorum. & 40 & 17,4 \\
\hline Total & 230 & 100 \\
\hline
\end{tabular}

Burada da taleplerin yerinde ve zamanında karşılanması noktasında bir memnuniyetsizlik olmasına rağmen bu durum birinci ifadeye göre daha düşük orandadır. Yani öğrenci işleri güler yüzlü olmamasına rağmen talepleri yerine getirmede daha iyi konumdadır.

\subsubsection{Fakülte idaresi}

Fakülte idaresi ile ilgili öğrencilerin tutumlarını öğrenme adına öğrenci işlerinde olduğu gibi bazı ifadeler verilmiş ve onlardan kendilerine en yakın olanı işaretlemeleri istenmiştir. Bununla ilgili tablolar aşağıdaki gibidir (Tablo 27, 28, 29, 30):

\begin{tabular}{|l|c|c|}
\hline \multicolumn{3}{|c|}{ Tablo 27: Öğrenciye yaklaşımı güler yüzlüdür. } \\
\hline & Sayı & Yüzde \\
\hline Katılmıyorum. & 149 & 64,8 \\
\hline Kararsızım. & 45 & 19,5 \\
\hline Katılıyorum. & 36 & 15,7 \\
\hline
\end{tabular}




\begin{tabular}{||l|c|c|}
\hline \multicolumn{3}{|c|}{ Tablo 27: Öğrenciye yaklaşımı güler yüzlüdür. } \\
\hline & Sayı & Yüzde \\
\hline Katılmıyorum. & 149 & 64,8 \\
\hline Kararsızım. & 45 & 19,5 \\
\hline Katılıyorum. & 36 & 15,7 \\
\hline Total & 230 & 100 \\
\hline
\end{tabular}

Tablo 27'deki verilere göre öğrencilerin \% 64,8'i yukarıdaki ifadeye katılmadığını yani idarenin kendilerine güler yüzlü yaklaşmadığını, \% 19,5'i bu konuda karar veremediğini, \% 15,7'si ise bu ifadeye katıldığını belirtmişlerdir.

\begin{tabular}{|l|c|c|}
\hline \multicolumn{3}{|c|}{ Tablo 28: Taleplerimize yerinde ve zamanında } \\
karşılık verilir. \\
\hline & Sayı & Yüzde \\
\hline Katılmıorum. & 166 & 72,2 \\
\hline Kararsızım. & 41 & 17,8 \\
\hline Katılıyorum. & 23 & 10,0 \\
\hline Total & 230 & 100 \\
\hline
\end{tabular}

Tablo 28'de yer alan ve idare ilgili olarak yöneltilen "taleplerimize yerinde ve zamanında karşılık veriliı" ifadesine katıldığını belirtenlerin oranı \% 10, katılmadığını söyleyenler \% 72,2, bu konuda kararsız olanlar ise \% 17,8' dir. Burada da idareye karşı bir memnuniyetsizlik vardir.

\begin{tabular}{||l|c|c|}
\hline \multicolumn{2}{|c|}{ Tablo 29: Öğrencilerin sorunlarıyla ilgilidir. } \\
\hline & Sayı & Yüzde \\
\hline Katılmıyorum. & 155 & 67,4 \\
\hline Kararsızım. & 49 & 21,3 \\
\hline Katılıyorum. & 26 & 11,3 \\
\hline Total & 230 & 100 \\
\hline
\end{tabular}

İdare “öğrencilerin sorunlarıyla ilgilidir” ifadesine katıldığını belirten öğrencilerin oranı \% 11,3, katılmayanlar \% 67,4, kararsızlar \% 21,3’tür.

\begin{tabular}{|l|c|c|}
\hline \multicolumn{3}{|c|}{ Tablo 30: İhtiyaç duyduğumda rahatlıkla } \\
görüşsebilirim. \\
\hline & Sayı & Yüzde \\
\hline
\end{tabular}




\begin{tabular}{|l|c|c|}
\hline Katılmıyorum. & 121 & 52,6 \\
\hline Kararsızım. & 47 & 20,4 \\
\hline Katılıyorum. & 62 & 27,0 \\
\hline Total & 230 & 100 \\
\hline
\end{tabular}

Tablo 30'daki “ihtiyaç duyduğumda rahatlıkla görüşebilirim” ifadesine öğrencilerin \% 27'si katıldığını, \% 52,6'sı katılmadığını, \% 20,4’ü kararsız olduğunu belirtmiştir. Bu verilere göre öğrencilerin diğer tutumlara nazaran idareden daha memnun oldukları, her hangi bir sıkıntı durumunda bunu rahatlıkla dile getirebildikleri görülmektedir.

İdare ile ilgili tutumlar genel anlamda değerlendirildiğinde bir memnuniyetsizliğin olduğu anlaşılmaktadır. Okumuş’un araştırmasında (2007: 81) buna benzer bir soruya farklı cevaplar verilmiştir. Deneklerin \% 46,3’ü fakülte yönetiminin kendilerine değer verdiğini, \% 66,3 de problemleriyle ilgilendiklerini belirtmiştir. Öğrencileri her iki çalışmada farklı şekilde söylemlere yönelten nedenlerin tespit edilip ortaya konulması ve buna göre bir yaklaşımın sergilenmesi gerekmektedir. Bunun yapılması öğrencilerin fakülteden memnun bir şekilde ayrılmasına, fakültedeki birlik ve beraberliğin sağlanmasına, fakültede yüksek kalitede ve verimde eğitimin verilmesine katkı sağlayacaktır.

\subsection{Fakülte Sonrası İle İlgili Tutumlar}

Fakülte sonrası ile ilgili olarak öğrencilere İlahiyat Fakültesinde okumaktan memnun olma durumları, alınan eğitime bağlı olarak düşüncelerinde bir değişikliğin meydana gelip gelmediği, ilahiyat vasfına sahip olup olmadıkları ve mezuniyet sonrası ne yapmak istedikleri sorulmuştur.

\subsection{1. İlahiyat Fakültesinde okumaktan memnun olma durumu}

Öğrencilerden İlahiyat Fakültesinde geçen hayatlarını ve buradan aldıkları eğitimi düşündüklerinde genel anlamda ne tür bir duyguya sahip olduklarını belirtmesi istenmiştir. Öğrencilerin \% 53,5’i İlahiyat Fakültesinde okumaktan memnun olduğunu, \% 29,5'i memnun olduğunu fakat gelecek kaygısı taşıdığını, \% 10'u ilahiyatta okuduğu için pişman olduğunu belirtmiştir. \% 7'si ise diğer seçeneğini işaretlemiştir (Tablo 31). Bu öğrenciler, İlahiyat Fakültesini gerektiği gibi değerlendiremediğini, daha kaliteli bir eğitim verilmesi gerektiğini, başka bir İlahiyat Fakültesinde okusaydı daha iyi olacağını ifade etmişlerdir.

\begin{tabular}{|l|c|c|}
\hline \multicolumn{3}{|c|}{ Tablo 31: Mezun olduktan sonra İlahiyat Fakültesi ile alakalı } \\
düşünceleriniz aşağıdakilerden hangisine daha uygundur? \\
\hline & Sayı & Yüzde \\
\hline
\end{tabular}




\begin{tabular}{||l|c|c|}
\hline $\begin{array}{l}\text { Memnunum, iyi ki İlahiyat } \\
\text { Fakültesinde okumuşum. }\end{array}$ & 123 & 53,5 \\
\hline $\begin{array}{l}\text { Memnunum, fakat gelecek kaygısı } \\
\text { taşıyorum. }\end{array}$ & 68 & 29,5 \\
\hline $\begin{array}{l}\text { Pişmanım, keşke İlahiyat } \\
\text { Fakültesinde okumasaydım. }\end{array}$ & 23 & 10,0 \\
\hline Diğer. Belirtiniz. & 16 & 7,0 \\
\hline Total & 230 & 100 \\
\hline
\end{tabular}

Görüldüğü gibi öğrencilerin yarısından fazlası ilahiyat eğitimi almaktan memnun olduklarını, bazı öğrenciler ise hem kendisinden hem de fakültenin şartlarından kaynaklanan nedenlerden dolayı arzuladıkları verimi elde edemediklerini söylemişlerdir. Okumuş’un çalışmasında (2007: 70) son sınıf öğrencilerinin çoğunluğu $(\% 73,4)$ İlahiyat okumaktan memnun olduğunu (\% 35,6) fakat gelecek kaygısı taşıdığını (\% 37,8) dile getirmişlerdir. Korkmaz'ın (2000: 193), Koç’un (2003: 38) ve Taştan vd.'nin çalışmalarında (2001: 184) da öğrencilerin büyük bir kısmı İlahiyat Fakültesinde okumaktan memnundur.

\subsubsection{Düşüncelerde değişiklik}

Öğrencilere fakülteye başladığınız zaman ile mezun olurken ki düşüncelerinizde bir değişiklik meydana gelip gelmediği, geldiyse bunun ne tür bir değişiklik olduğu sorulmuştur. Verilen cevaplara göre oluşan tablolar aşağıdaki gibidir (Tablo 32, 33):

\begin{tabular}{|l|c|c|}
\hline \multicolumn{2}{|c|}{$\begin{array}{r}\text { Tablo 32: İlahiyat Fakültesine başlangıçtaki düşünceleriniz ile } \\
\text { mezun olurkenki düşünceleriniz arasında bir değişiklik } \\
\text { meydana geldi mi? }\end{array}$} \\
\hline & Say1 & Yüzde \\
\hline Evet & 138 & 60,0 \\
\hline Hayır. & 24 & 10,4 \\
\hline Kısmen. & 68 & 29,6 \\
\hline Total & 230 & 100 \\
\hline
\end{tabular}

Öğrencilerin \% 60’’ düşüncelerinde değişiklik meydana geldiğini, \% 29,6'sı kısmen değişim yaşandığını, \% 10,4'ü ise herhangi bir değişimin olmadığını ifade etmişlerdir. Öğrencilerin büyük çoğunluğunda düşünce açısından bir farklılaşma olmuştur. Taştan vd.'nin yaptığı çalışmada (2001: 188) da deneklerin \% 60,4'ü bu soruya evet, \% 34,7'si kısmen, \% 4,9'u hayır cevabını vermiştir. 
Öğrencilere bu farklılaşmanın türü sorulduğunda; kendilerinde değişiklik olduğunu belirten 206 öğrencinin \% 58,7'si kişilik, bilgi, görüş ve düşüncesinde değişim olduğunu, \% 18'i eleştirel bir düşünce yapısına sahip olduğunu, \% 15'i daha çok okumaya ve kendini geliştirmeye başladığını belirtmiştir. \% 8,3'ü ise dine ilgisinde bir azalma olduğunu ifade etmiştir (Tablo 33).

\begin{tabular}{|l|c|c|}
\hline \multicolumn{3}{|c|}{ Tablo 33: Değişikliğin türü } \\
\hline & Sayı & Yüzde \\
\hline $\begin{array}{l}\text { Kişilik, bilgi, görüş ve düşüncemde } \\
\text { değişiklik oldu. }\end{array}$ & 121 & 58,7 \\
\hline $\begin{array}{l}\text { Daha çok okumaya ve kendimi } \\
\text { geliştirmeye başladım. }\end{array}$ & 31 & 15,0 \\
\hline $\begin{array}{l}\text { Eleştirel bir düşünce yapısına sahip } \\
\text { oldum. }\end{array}$ & 37 & 18,0 \\
\hline Dine karşı ilgimde azalma oldu. & 17 & 8,3 \\
\hline Total & 206 & 100 \\
\hline
\end{tabular}

Taştan vd.'nin araştırmasında (2001: 189) \% 84,4 kişilik bilgi, görüş ve düşüncesinde değişiklik olduğunu söylemiştir. \% 9,1 daha çok okumaya ve kendini geliştirmeye başladığını, \% 3,9 eleştirel bir düşünce yapısına sahip olduğunu, \% 2,6 dine ilgide bir azalma olduğunu belirtmiştir. Görüldüğü gibi İlahiyat Fakültesinden mezun olurken öğrencilerin kişilik, bilgi, görüş, düşünce, daha çok okuma ve araştırma, olayları sorgulama ve dine bakış noktasında bir farklılaşma meydana gelmiştir. Yalnız dinî içerikli bir eğitim veren fakültede öğrencilerin fakülteden mezun olurken dine bakışlarında bir azalmanın meydana gelmesi önemli bir sorun olarak görülmeli ve bunun nedenleri üzerinde durulmalıdır. Öğrenciler hangi tür sebeplerden ötürü dinden soğumaya ve ona karşı ilgilerini kaybetmeye başlamışlardır?

\subsection{3. İlahiyat vasfina sahip olma}

Öğrencilerden, mezun olurken ilahiyat öğrencisinin sahip olması gereken vasıflara sahip olup olmadıklarını değerlendirmeleri istenmiştir. Öğrencilerin \% 14'ü tamamen, \% 53’ü kısmen sahip olduklarını söylemiştir. Bu vasfa sahip olmadıklarını belirtenlerin oranı ise \% 33'tür (Tablo 34). Bu sonuçların benzer çalışmalarla örtüştügü görülmektedir (Mehmedoğlu, 2000: 147) (Okumuş, 2007: 84).

\begin{tabular}{|l|}
\hline \multicolumn{2}{|c|}{ Tablo 34: Fakülteden mezun olurken ilahiyat öğrencisinin } \\
sahip olması gereken vasıflara sahip olduğunuzu düşünüyor \\
musunuz? \\
\hline \multicolumn{3}{|c|}{ Sayı } & Yüzde \\
\hline
\end{tabular}




\begin{tabular}{||l|c|c|}
\hline Evet & 32 & 14,0 \\
\hline Hayır & 76 & 33,0 \\
\hline Kismen & 122 & 53,0 \\
\hline Toplam & 230 & 100 \\
\hline
\end{tabular}

\subsubsection{Mezuniyet sonrası düşünce}

Son olarak öğrencilerden mezun olduktan sonra ne yapmak istediklerine dair görüşlerini belirtmeleri istenmiştir. Bu soruya öğrencilerin \% 44,3'ü öğretmen olmak, \% 32,2'si akademik kariyer yapmak, \% 5,7'si yeni bir üniversite okumak, \% 5,2'si yurtdışına gitmek, \% 3,9'u diyanet bünyesinde görev almak, \% 3'ü serbest çalışmak şeklinde cevap vermiştir. \% 5,7'si ise diğer seçeneğini işaretlemiştir (Tablo 35). Bu öğrenciler düşüncelerini "kararsızlık, medrese okumak, siyasete atılmak, ücretsiz olarak dine hizmet etmek" şseklinde ifade etmişlerdir.

\begin{tabular}{|l|c|c|}
\hline \multicolumn{3}{|c|}{ Tablo 35: Mezuniyet sonrası düşünceniz nedir? } \\
\hline & Sayı & Yüzde \\
\hline Yeni bir üniversite okumak. & 13 & 5,7 \\
\hline $\begin{array}{l}\text { İmam-Hatip, K.Kursu öğreticisi } \\
\text { olmak. }\end{array}$ & 9 & 3,9 \\
\hline Öğretmen olmak. & 102 & 44,3 \\
\hline Akademik kariyer yapmak. & 74 & 32,2 \\
\hline Yurtdışına gitmek. & 12 & 5,2 \\
\hline Serbest çalışmak. & 7 & 3,0 \\
\hline Diğer. Belirtiniz & 13 & 5,7 \\
\hline Toplam & 230 & 100 \\
\hline
\end{tabular}

Başka araştırmalarda (Koç, 2003: 55) (Taştan, Kuşat \& Çelik, 2001: 187) deneklerin çoğunluğu öğretmenlik yaparken yüksek lisans eğitimi almak, akademik kariyer yapmak ve diyanet işleri bünyesinde çalışmak şeklinde belirtmiştir.

\section{SONUÇ}

İlahiyat Fakültelerinin, üstlenmiş oldukları misyon açısından ülkemizdeki yüksek örgün eğitim kurumları içinde önemli bir yeri bulunmaktadır. Hem devletin çeşitli alanlarda istihdam edeceği din adamı ihtiyacını karşılama hem de toplumunun dinî bakımdan doğru bilgilendirilmesi noktasında hayati görevleri yüklenmişlerdir. Bundan dolayı verilen eğitimin ve burada yetişen öğrencilerin nitelikli olması önem arz etmektedir.

Araştırmamız çerçevesinde incelediğimiz örneklem grubundaki öğrencilerin \% 69,2'si dinini doğru öğrenmek ve öğretmek ve din hizmetlerinde görev almak için bu fakülteyi tercih 
ettiğini belirtmiştir. $\mathrm{Bu}$ bize öğrencilerin çoğunun bilinçli bir şekilde İlahiyat Fakültesini tercih ettiğini göstermektedir. \% 55,7'lik bir kesim kendisini kişilik noktasında “dini konularda yetersiz bilgiye sahip, kendine güvensiz, sosyal ilişkilerde zayıf” olarak düşünmektedir. Dolayısıyla İlahiyat Fakülteleri, söz konusu eksikliklerin tamamlanıp sosyalleşmeyi sağlayan ve bu şekilde hem bireye hem de topluma yönelik faydaları içinde barındıran eğitim kurumları olarak düşünülmektedir. Ancak mezun olan öğrencilerin kişilik noktasında hâlâ bunları dile getirmesi, fakülteden bu hususta istenen beklentinin karşılanamadığını göstermektedir.

Öğrencilerin lisans eğitimi boyunca Arapça eğitiminde zorlandığı görülmektedir. Bunun sebeplerine dair hem öğrencilerin geçmişten gelen alt yapı eksikliğinin olması hem de dersi veren öğretim elemanlarının formasyon ve öğrenciye yaklaşımından kaynaklanan bazı problemlerin etkili olduğu söylenebilir. Arapça dersinden sonra öğrenciler en fazla Felsefe ve Din Bilimleri derslerinden zorlanmalarına rağmen ilahiyat müfredatında bu derslerin yer almasını gerekli görmektedirler. Dersler dışında ilahiyat öğrencilerinin neredeyse tamamı formasyon verilmemesini kendileri için büyük bir sıkıntı olarak görmektedirler. Lisans sonrası verilen formasyon kontenjanlarının yetersiz olması ve bunun için ekstra bir maddi külfete katlanma öğrenciler için problem teşkil etmektedir.

Öğrencilerin hocalarından beklentilerine bakıldığında \% 49,6 dersini iyi anlatmasını, \% 22,2 öğrenciyle sosyal ilişkilerinin iyi olmasını ve \% 20,8 üniversite sonrası için kendilerine rehberlik etmesini istemektedir. Görüldüğü gibi hocaların ders ve rehberlik açısından öğrencilere yardımcı olması beklenmektedir.

Diğer konularda öğrencilerin değerlendirmelerine bakıldığında \% 56,1 geleneksel din anlayışına ters düşen fikirlerin tartışılmasını faydalı bulmakta; \% 57,3 eğitimin kız-erkek ayrı verilmesini istemekte, öğrencilerin yarıdan fazlası öğrenci işlerinin ve idarenin kendilerine yaklaşımından memnun olmadıklarını; \% 60 aldıkları eğitimin, düşüncelerinde bir değişim meydana getirdiğini; bunun kişilik, bilgi görüş ve düşünce ( $\% 58,7)$, eleştirel düşünce yapısına sahip olma (\% 18), daha çok okuyarak kendini geliştirme (\% 15) ve dine karşı ilgide azalma (\% 8,3) şeklinde dile getirmektedir.

Genel olarak bakıldığında ise öğrencilerin \% 83'ü İlahiyat Fakültesinde okumaktan memnun olduğunu belirtmektedir. \% 53'ü ilahiyat öğrencisinin sahip olması gereken vasıflara kısmen, \% 14'ü tamamen sahip olduğunu, \% 33'ü ise sahip olmadığını söylemektedir. Mezun olduktan sonra öğrencilerin \% 44,3'ü öğretmen olmak istediğini, \% 32,2'si akademik kariyer yapmayı düşündüğ̈nü, \% 5,9'u yeni bir üniversite okuyacağını, \% 5,2'si yurtdışına gideceğini, \% 3,9'u 
Diyanet bünyesinde görev almak istediğini ve \% 3'ü serbest çalışacağını ifade etmiştir. Geri kalan \% 5,7 ise düşüncelerini "kararsızlık, medrese okumak, siyasete atılmak, ücretsiz olarak dine hizmet etmek" şeklinde belirtmişlerdir.

$\mathrm{Bu}$ çalışmadaki veriler araştırmacının gözlemleri dışında çoğunlukla öğrencilerin bakış açısını yansıtmaktadır. Onların dile getirmiş olduğu problem ve sıkıntılar aynı zamanda bunların eğitim ve hocalar bakımından nasıl bir fakülte hayal ettiklerini göstermesi açısından önemlidir. Bunun için dile getirilen hususların dikkate alınması ve buna yönelik benzer çalışmaların yapılması fakülte-öğrenci-hoca üçgeninde ilişkilerin sağlıklı yürümesi ve bu fakültelerin birey ve topluma yönelik sorumluluklarını yerine getirmesi bakımından önemlidir.

\section{KAYNAKÇA}

Ay, M. E. (2000). “1999-2000 Öğretim Y1lında Fakültemize Gelen 1. Sınıf Öğrencileri Üzerine Bir Araştırma”, Uludă̆ Üniversitesi İlahiyat Fakültesi Dergisi, 9 (9), 227-243.

Ayhan, H. (1999a). "Cumhuriyet Dönemi Din Eğitimine Genel Bakış”, Ankara Üniversitesi Ilahiyat Fakültesi Dergisi, 39 (2), 237-254.

Ayhan, H. (1999b). “İlahiyat Fakültesi”, Din Eğitimi Araştırmaları Dergisi, 6, 255-268.

Cengil, M. (2009). "Hitit Üniversitesi İlahiyat Fakültesi 1. Sınıf Öğrencilerinin Benlik Saygısı Düzeylerinin Çeşitli Değişkenler Açısından İncelenmesi”, Hitit Üniversitesi Çorum İlahiyat Fakültesi Dergisi, 8 (15/1), 77-102.

Firat, E. (1989). "İlahiyat Fakültesi Öğrencilerinin Problem Olarak Değerlendirdikleri Eğitimleriyle İlgili Konular”, Dokuz Eylül Üniversitesi İlahiyat Fakültesi Dergisi, 6, 17-42.

Furseth, I. \& Repstad, P. (2011), Din Sosyolojisine Giriş: Klasik ve Çağdaş Kuramlar, Çeviri ve Notlar: Çapcıoğlu, İ. \& Aydınalp, H., Ankara: Birleşik Yayınları

Kımter, N. (2008). Benlik Saygısı ve Dindarlık İlişkisi, Uludağ Üniversitesi Sosyal Bilimler Enstitüsü (Yayınlanmamış Doktora Tezi), Bursa.

Kirman, M. A. \& Aydınalp, H. (2006). "İlahiyat Fakültesi Öğrencilerinin Problem ve Sorunları”, Kahramanmaraş Sütçü İmam Üniversitesi İlahiyat Fakültesi Dergisi, 4 (7), 93123.

Koç, A. (2003). "İlahiyat Fakültesi (İlahiyat Lisans Programı) Öğrencilerinin Sorunları”, Marmara Üniversitesi İlahiyat Fakültesi Dergisi, 25 (2), 25-64. 
Korkmaz, M. (2000). “İlahiyat Fakültesi Öğrencilerinin Fakülteyi Tercih Nedenleri: Erciyes Üniversitesi İlahiyat Fakültesi Örneği”, Bilimname, 8 (18), 167-204.

Kurt, A. (2009). İşadamlarında Dindarlık ve Dünyevileşme, Bursa: Emin Yayınları.

Okumuş, E. (2007). “İlahiyat Fakültesi Öğrencilerinin Problemleri (Dicle Üniversitesi Örneği)", Dĕgerler Ĕ̆itimi Dergisi, 5 (13), 59-94.

Mehmedoğlu, Y. (2000). “İlahiyat Fakültesi Öğrencilerinin Eğitim-Öğretim Beklentileri”, Tartışmalı İlmî Toplantılar Dizisi: Gençlik Dönemi ve Eğitimi, İstanbul: Ensar Neşriyat, 121150.

Taşkıran, A. (2013). “İlahiyat Fakültesi Müfredatında Felsefe ve Din Bilimleri Bölümü Derslerinin Yeri ve Fonksiyonlarına Dair Bir Araştırma (İlahiyat Fakültesi Öğrencileri Örneği)", Kahramanmaraş Sütçü İmam Üniversitesi İlahiyat Fakültesi Dergisi, 11 (22), 238266.

Taştan, A., Kuşat, A. \& Çelik, C. (2001). "Üniversite Düzeyinde Din Öğretimi Alan Öğrencilerde Eğitim Sürecinde Oluşan Tutum ve Davranış Değişiklikleri (Erciyes Üniversitesi İlahiyat Fakültesi Örneği)”, Erciyes Üniversitesi Sosyal Bilimler Enstitüsü Dergisi, 11, 169-192.

Toktaş, F. \& Acuner, H. Y. (2004). “ İlahiyat Fakültelerinde Felsefe Dersleri: On Dokuz Mayıs Üniversitesi İlahiyat Fakültesi Örneği” On Dokuz Mayıs Üniversitesi İlahiyat Fakültesi Dergisi, 17, 159-176.

Varış, F. (1974). “Üniversitenin Değișen Fonksiyonu ve Birkaç Sorun”, Ankara Üniversitesi Eğitim Bilimleri Fakültesi Dergisi, 7 (1), 345-360. 